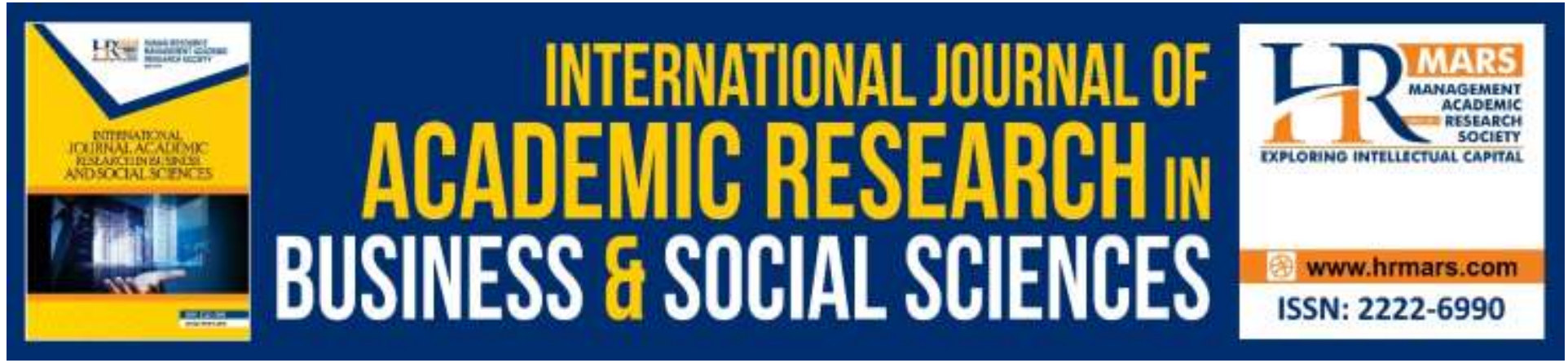

\title{
The Influence of Demographic Factors on Tax Payercompliance in Uganda
}

\section{Warui Waweru Fredrick, Otai Isaac Peter}

To Link this Article: http://dx.doi.org/10.6007/IJARBSS/v9-i9/6328

DOI: $10.6007 /$ IJARBSS/v9-i9/6328

Received: 30 July 2019, Revised: 01 August 2019, Accepted: 30 August 2019

Published Online: 09 September2019

In-Text Citation:(Fredrick \& Peter, 2019)

To Cite this Article: Fredrick, W. W., \& Peter, O. I. (2019). The Influence of Demographic Factors on Tax Payercompliance in Uganda. International Journal of Academic Research in Business and Social Sciences, 9(9), 537-556.

\section{Copyright: (c) 2019 The Author(s)}

Published by Human Resource Management Academic Research Society (www.hrmars.com)

This article is published under the Creative Commons Attribution (CC BY 4.0) license. Anyone may reproduce, distribute, translate and create derivative works of this article (for both commercial and non-commercial purposes), subject to full attribution to the original publication and authors. The full terms of this license may be seen at: http://creativecommons.org/licences/by/4.0/legalcode

Vol.9,No.9, 2019,Pg. 537 - 556 


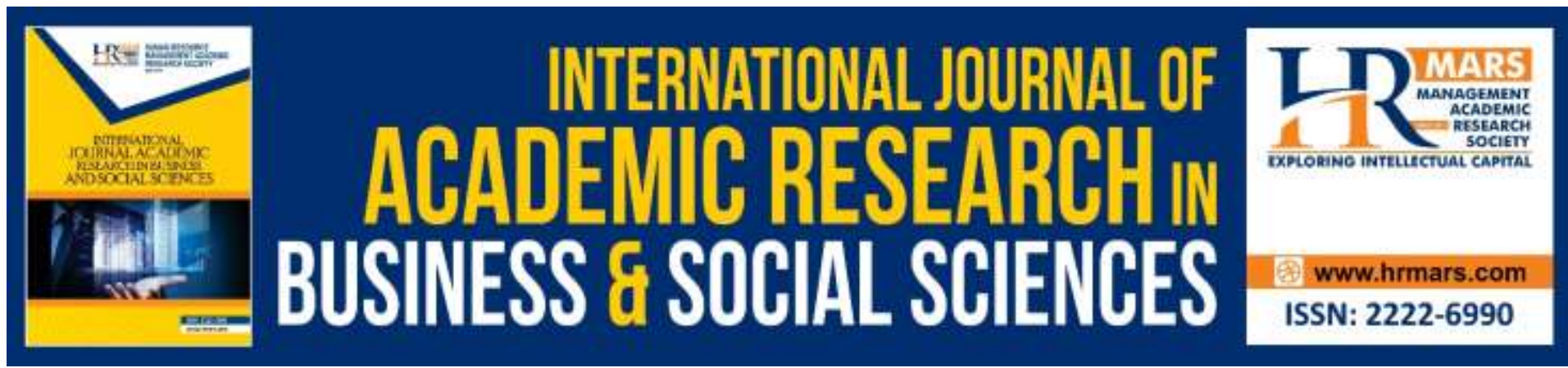

\title{
The Influence of Demographic Factors on Tax Payercompliance in Uganda
}

\author{
Dr.Warui Waweru Fredrick \\ Lecturer Kenyatta University,School of Business, Department of Accounting and Finance
}

\begin{abstract}
Otai Isaac Peter
Assistant lecturer Kyambogo University, School of management and entrepreneurshipDepartment of accounting and Finance
\end{abstract}

\begin{abstract}
This article examines the influence of demographic factors on tax payer compliance in Uganda, by specifically looking at individual tax payers who are sole proprietors and owners of Small and Medium Enterprises. Administrative data that was based on a survey conducted by Uganda Revenue Authority, on "attitudes to tax morale and compliance, and the role Uganda Revenue Authority can play in improving tax morale and compliance in the country" was used for the study. The study adopted a quantitative approach, with taxpayers as the respondents. The study findings are based on raw data from a survey conducted by Uganda Revenue Authority. The raw data was then analyzed using Statistical Package for Social Scientists, where factor analysis and correlational analysis was used to determine the influence of demographic factors on tax payer compliance. The survey distributed questionnaires to 284 respondents, of which 284 responses were received, reflecting a response rate of $100 \%$. The findings show that gender is significant while age and education are not significant. The article recommends that government should introduce policies that should make tax compliance friendlier. For example government should conduct country wide tax education for owners of small scale businesses and sole proprietors. Government should also introduce incentives for voluntary tax compliance.
\end{abstract}

Keywords: Demographic Factors, Taxpayer Compliance, Individual Taxpayers

\section{Introduction}

Tax is defined as 'a compulsory levy, imposed by government or other tax raising body, on income, expenditure, or capital assets, for which the taxpayer receives nothing specific in return (Lymer \& Oats, 2009).Tax is a source of revenue to the government of a country. Individuals and companies pay various taxes to the government (Omagor \& Mubiru, 2008). Governments use tax as part of measures to control the economy (Romer \& Romer, 2010). 
Tax revenue is powerful resource to funding the public payments of developed, developing and underdeveloped countries in the world (Fjeldstad \& Semboja).

Taxes are also expected to ensure economic goals through the ability of the taxation system to influence the allocation of resources including transferring resources from the private sector to the government to finance the public investment programmes, the direction of private investment into desired channels through such measures as regulation of tax rates and the granting of tax incentives. In addition, import duties could be used to protect local industries from foreign competition. This has the effect of transferring a certain amount of demand from imported goods to domestically produced goods.

But the amount of revenue to be generated by a government from taxes for its expenditure program depends on the willingness of the taxpayers to comply with tax laws of a country (Fjeldstad \& H C, 2012). An important issue for any government and revenue collecting authority is to obtain knowledge and understanding of the reasons for taxpayer noncompliance. However, measurement of the magnitude of intentional and unintentional noncompliance can be difficult as it involves estimating levels of uncollected tax, which by its nature is not detected by the revenue authority (Omagor \& Mubiru, 2008).

In developing countries many problems like poor administration, failing to collect sufficient tax revenues, tax structures where tax horizontal and vertical equity considerations are not integrated, lack of government and economic stability are common (Tesfaye, 2015). Besides, degree of tax compliance in most these countries is affected by demographic, individual, social, economic and institutional factors (Kirchler \& Cambridge, 2007) and (Loo, 2006). Since each country has its own approach to managing tax compliance attitude and each has different tax laws and regulations for the factors affecting tax compliance attitude appear to vary among countries (Palil, 2010).

Countries like Uganda are still characterized by the low income tax compliance levels, in the face of the numerous advocacies for voluntary tax compliance (Ayoki, Obwona, \& Ogwapus, 2005); (Kangave, 2005). Many of such governments have adopted tax compliance administrative measures like penalties, rates and tax audits to ensure tax enforcement instead of voluntary compliance (Kayaga , 2007), which have still failed to yield.

According to Uganda Revenue Authority, 2017/2018, in the Financial Year 2017/18, net revenue of Uganda shillings $14,456.11$ billion was collected posting a significant growth of Uganda shillings 1,736.48 billion (13.65\%) compared to the Financial Year 2016/17. However, the collections were Uganda shillings 606.32 billion below the Financial Year 2017/18 target of Uganda shillings 15,062.43 billion.

\section{Demographic Factors}

According to(Tittle, 1980), the relationship between demographic factors and tax compliance has been attracting many researchers' attention in the last few decades. Jackson \& Milliron, (1986) state that age, gender, and education as major demographic factors have evidence on their relationship with tax compliance in which demographic factors affect tax compliance. They also claim that taxpayers' age as a common demographic variable. Based on Fischer et al (1992), demographic variables have an indirect effect on taxpayer compliance by their impacts on noncompliance opportunities and attitudes.

A lot of studies have been carried out on the impact of Demographic factors like age, gender and education on taxpayer compliance. Studies on the impact of age on taxpayer compliance have posted contrasting findings; studies by (Tittle, 1980), (Warneryd \& 
Walerud, 1982) and (Wahlund, 1992) postulate negative association between taxpayer compliance and age; indicating that older people are less compliant. In contrast, Dubin, Graetz, \& Wilde, (1987) argued that age was positively related with taxpayer compliance. Some studies however, have found no relationship between age and taxpayer compliance. Studies by (Preager \& Torgler, 2007), and (Mohani, 2001)also found that older people are more compliant than young people.

Studies on the impact of gender on taxpayer compliance also show contrasting findings. Studies by Hasseldine \& Hite, (2003), and (Tittle, 1980) found that female taxpayers were more compliant than males. In difference, (Richardson, 2006), (Amina \& Sniy, 2015) and (Niway, 2016) pointed out that gender has no significant impact on compliance attitude of taxpayers.

There is also literature supporting direct, positive relationship between educational level and taxpayer compliance (Bhatia, 1976), (Chan, Troutman, \& O'Bryan, 2000), (Jackson \& Milliron, 1986),(Kirchler \& Cambridge, 2007), and(Niway, 2016) also suggested that education level is directly linked to a likelihood of compliance attitude. Educated taxpayers are more compliant than uneducated taxpayers.

Thus, the concentration of this article in tax compliance problem is on the demographic factors (gender, age and education) which affect taxpayers' behaviours related to their tax responsibilities.

\section{Gender}

According to Schuetze (2002) gender is a sociological aspect that influences the noncompliance behavior of an individual tax payers. Widely held studies establish that the level of compliance between female and male varies such that male had high level of noncompliance than females.

Many studies have reported that male and female taxpayers display different levels of tax compliance (Friedland, Maital, \& Rutenberg, 1978); (Cadsby, Maynes, \& Trivedi, 2006); (Alm, Cherry, Jones, \& Mckee, 2010)). Spicer and Hero (1985), for example, found that female participants were more compliant than male ones in a laboratory experiment. However, "women are more likely to evade paying tax than men, but underreport a much smaller fraction of their income than men" (Friedland, Maital, \& Rutenberg, 1978)). Bordignon (1993) suggested that male taxpayers are greater risk-takers than their female counterparts, which may explain why male taxpayers comply less than female taxpayers.

\section{Age}

Age is demographic factor that impacts the level of tax compliance or tax non-compliance behavior of individual tax payers. A majority of studies done in the United States show that age is a key factor in explaining the degree of tax non-compliance.

Having many older taxpayers might be advantageous in terms of their contribution to overall compliance levels in a country. Previous research has found that the age of taxpayers correlates positively with the tax compliance level (Clofter, 1983); (Kirchler E. , 1999); (Fjeldstad \& Semboja, 2001); (Alm, Cherry, Jones, \& Mckee, 2010). (Clofter, 1983) found that taxpayers aged 65 and above are more compliant than younger taxpayers. Older taxpayers' risk-averse attitudes may prompt them to comply more than younger taxpayers (Chang, Nichols, \& Schultz, 1987). 


\section{Education}

Another demographic variable is education. This refers to the tax payers' ability to understand and to either comply or not comply with taxation rules. Research done in Australia revealed that most educated taxpayers recorded high tax compliance that those with limited education.

The impact of education on tax compliance also produces mixed results in tax compliance studies. Education and tax compliance levels might positively correlate (Jackson \& Milliron, 1986); (Dubin \& Wilde, 1988); (Richardson, 2006); (Saad, Fairness, perceptions and compliance behaviour: The case of salaried taxpayers in Malysia after inplementation of of the self assesment system, 2010). Richardson (2006) found a positive relationship between education and tax compliance levels. Similarly, Dubin \& Wilde, 1988 demonstrated that taxpayers with high levels of general education are less likely to be non-compliant taxpayers than those with low levels of education. The positive correlation between tax compliance and education level is attributed to improved tax fairness perceptions when taxpayers are better educated and with a capacity to deal with complex tax laws (Dubin, Graetz, \& Wilde, 1990); (Saad, 2010).

On the other hand, highly educated taxpayers also have the capacity to exploit loopholes in tax laws to reduce their tax liabilities (Jackson \& Milliron, 1986); (Dubin et al 1990). Moreover, a high level of education may change the perceptions of the payment of income taxes from a reduction of income to a loss, consequently reducing tax compliance (Chang et al., 1987).

\section{Tax Compliance}

Tax compliance matter is a behavioural issue; it is either a taxpayer pays voluntarily or coerced to pay (Fagbeni \& Abogun, 2015).

There is no standard all-embracing definition of compliance adopted across all tax compliance studies. For example, taxpayer compliance has been defined as compliance with reporting requirements, meaning that the taxpayer files all required tax returns at the proper time and that the returns accurately report tax liability in accordance with the internal revenue code, regulations and court decisions applicable at the time the return is filed (Roth, Scholz, \& Witte, 1989). An alternative definition has been offered by (James \& Alley, 1999) that considers tax compliance in terms of the tax gap. This is the difference between 'true' individual income tax liability and that finally collected on a voluntary basis or by enforcement action: However, this latter definition has also been viewed as somewhat simplistic.

A more specific definition of tax compliance has been viewed by some authors. According to a definition provided by Allingham \& Sandmo, 1972, tax compliance is a condition of taxpayers reporting their actual income where the self-assessment system that creates an uncertain condition would trigger a non- compliance behaviours. For example, there is a possibility of taxpayers enjoy tax savings by hiding their income, not reporting their tax income, and under- reporting their taxable income. This specific definition takes into account the possibility of intentionality of taxpayers to not obey the tax laws. Hence, this definition is not only related to tax obligations of taxpayers such as submitting tax return on time, but it also considers the possibility of tax frauds. 
From all of the definitions above, it can be concluded that tax compliance is the degree when the tax behaviour of taxpayers is already appropriate to the country's tax laws including tax calculation and timely manners. Thus, tax compliance expected by government is not the compliance that is forced by government, but the voluntary tax compliance. Specifically, voluntary tax compliance is defined by James, et al (2002) as compliant behaviours of taxpayers to fulfill their tax obligations based on tax laws without any forces from government such as fear of getting punishments. Thus, if all of taxpayers have high tax awareness, the tax gap will be smaller.

\section{Uganda Revenue Authority}

Uganda Revenue Authority (URA) is a semi-autonomous Agency established in September 1991 by an Act of Parliament. URA is charged with the primary responsibility of assessing, collecting and accounting for Government tax and non-tax revenues to finance and sustain the national recurrent and development expenditure. URA also advises government on Tax policy issues.

The primary role of URA in Uganda's Development Agenda (Millennium Development Goals (MDGs) and Sustainable Development Goals (SDGs)) is the mobilization of adequate financial resources (Revenue) to finance Government programmes. Uganda Revenue Authority draws this responsibility from her mandate of Assessing, collecting and accounting for all Government Tax and Non-tax revenue and advising Government on Tax Policy issues. External financing is highly unpredictable and sometimes has strings attached, therefore URA has to continuously provide excellent services and excel other business to be able to finance a greater proportion of the Central Government Budget and ultimately reduce Donor dependency and borrowing.

\section{Objectives of Uganda Revenue Authority (URA) Maximize Revenue}

URA's outcome objective is to maximize revenue in order to finance Government expenditure and reduce donor dependency. The major initiatives implemented to maximize revenue by URA include; normal flow monitoring, strengthen timely revenue reconciliation and reporting, management of objections and disputes resolution, ensuring financial prudence at all times through optimal use of scarce resource.

\section{Increase Compliance}

It is the duty of taxpayers to comply with tax laws over and above the actual payment of tax. URA has put in place mechanisms to compel taxpayers to comply with their tax duties. Compliance in Tax administrations is about registration, filling, payment and declaration. It's also about compliance with tax and customs laws, regulations and guidelines.

\section{Optimize Stakeholder Relations}

Optimizing Stakeholder relations as a key pillar seeks to increase stakeholder participation in process development and revenue mobilization. Tax administration is an enormous task and therefore there is need to bring on board different partners.

\section{Improve Quality of Service}


The quality of service has an effect on the compliance levels and revenue collection. It is therefore important for URA to maintain excellent service in order to guarantee voluntary compliance. URA is a client focused and responsive organization and therefore client satisfaction is its priority and therefore its aim is offering taxpayers excellent services with passion and purpose.

\section{Transform our Processes}

Businessprocessmanagementisasystematicapproachtomakinganorganization'sworkflowmor e effective, more efficient and more capable of adapting to an ever-changing environment. These processes can affect the cost and revenue generation of an organization. In order to make it easy for its clients to meet their tax obligations and be able to increase the taxpayer register, several processes that need to be continually improved were identified and efforts made to improve them.

\section{Improve our People}

Improve our people objective focuses at staff productivity levels, staff integrity, staff motivational levels and employ staff levels. To this effect, URA planned to implement various initiatives that include a robust staff recruitment program, a comprehensive staff training program, enriched staff maintenance programs and structural review and alignment to strategy.

\section{Statement of the Problem}

Tax income is the major source of the government revenue to finance public expenditure. It is paid by citizens as an obligation without expecting any direct benefit in return. Even if tax is the base for the existence of the state, most taxpayers become unwilling to pay their tax obligations due to the presence of negative voluntary compliance.

According to the Tax Justice Network, 2011, efforts by governments to generate tax revenues are hampered by widespread tax evasion among taxpayers in many countries. It further states that tax revenues lost through tax evasion worldwide is estimated to be above US\$ 3.1 trillion which accounts for about 5.1\% of world Gross Domestic Product. This translates to about $54.9 \%$ of healthcare spending lost to tax evasion. The Tax Justice Network also states that the impact of deliberate failure to pay tax to government is more severe in the developing countries. For example, $97.7 \%$ and $138.5 \%$ of health care budget is lost to tax evasion in African countries and South American countries respectively. However, the desire to evade tax is prevalent in every country and this phenomenon has attracted numerous scholars to investigate the factors behind it.

Table 1: Showing summary of revenue performance in Uganda Amounts are in billions of Uganda shillings

\begin{tabular}{|l|l|l|l|l|l|}
\hline $\begin{array}{l}\text { Financial } \\
\text { Year }\end{array}$ & $\begin{array}{l}\text { Targeted } \\
\text { Revenue }\end{array}$ & $\begin{array}{l}\text { Actual } \\
\text { Revenue }\end{array}$ & Divergence & Performance & $\begin{array}{l}\text { Non Compliance } \\
\text { Rate }\end{array}$ \\
\hline $2014 / 2015$ & $9,576.59$ & $9,715.60$ & 139.01 & $101.45 \%$ & Nil \\
\hline $2015 / 2016$ & $11,635.42$ & $11,230.87$ & $(404.54)$ & $96.52 \%$ & $3.48 \%$ \\
\hline $2016 / 2017$ & $13,177.15$ & $12,719.63$ & $(457.51)$ & $96.53 \%$ & $3.47 \%$ \\
\hline $2017 / 2018$ & $15,062.43$ & $14,456.11$ & $(606.32)$ & $95.97 \%$ & $4.03 \%$ \\
\hline
\end{tabular}


Source: Uganda Revenue Authority Annual Reports: 2014-2015, 2015-2016, 2016-2017, 2012018

According to the table above the rate of non-compliance has been increasing from $3.48 \%$ in $2014 / 2015$ to $4.03 \%$ in $2017 / 2018$.

Despite the implementation of modern systems and procedures for investor support, ranging from introduction of e-tax, taxpayer's education services and faster handling of complaints, the total amount collected remains lower than the targeted. This is attributed to non-tax compliance of the tax payers among other factors.

Several studies have been carried out to establish the factors that influence taxpayer compliance. These studies have established factors such as; attitude and perceptions of the taxpayer towards taxation, peer influence, demographic factors, cultural factors, taxpayer awareness and noncompliance opportunity among others.

Whereas most studies have established factors that influence taxpayer compliance, the focus of this paper is to examine how one of the factors, demographic factors, influences taxpayer compliance. Some studies including; Kirchler (1999), and Saad (2010), have examined the influence of demographic factors on taxpayer compliance with contrasting findings.

In Uganda, the influence of demographic factors on taxpayer compliance has arguably not been examined. The aim of this paper is to address this gap by considering three demographic factors; gender, age and education.

\section{Study Objectives}

The aim of the study is to carry out an examination of the influence of demographic factors on taxpayer compliance in Uganda.

The specific objectives of the study are to;

i. To investigate the impact of gender on taxpayer compliance in Uganda

ii. To investigate the impact of age on taxpayer compliance in Uganda

iii. To investigate the impact of education on taxpayer compliance in Uganda.

\section{Hypothesis}

$\mathrm{Ho}_{1}$ Gender has no impact on taxpayer compliance

$\mathrm{Ho}_{2}$ Age has no impact on taxpayer compliance

$\mathrm{Ho}_{3}$ Education has no impact on taxpayer compliance

\section{Scope of the Study}

Unlike most compliance studies that have concentrated on establishing the factors affecting tax compliance, this study identifies demographic factors as one of the factors affecting tax compliance and goes ahead to examine how demographic factors affects tax compliance. The study targeted individual tax payers who are sole proprietors and Small Scale Enterprise owners. Information about them was obtained through analyzing raw data provided by a survey conducted by Uganda Revenue Authority.

\section{Significance of the Study}

The results of this study may be significant from a theoretical standpoint in that the study may contribute towards developing a comprehensive theory of tax compliance.

From a practical standpoint the findings may be of help for policy makers who will gain a 
better understanding of the factors that determine compliance for policy interventions.

The suggested recommendations can be useful in enabling URA to come up with possible strategies on improving tax compliance by citizens and also improve on revenue performance.

Most studies on tax compliance have concentrated on establishing the factors that influence tax compliance generally, but have not critically established the extent to which demographic factors, peer influence and tax payer awareness contribute to tax compliance. This intends to bridge that gap.

The study may enrich the literature on tax compliance upon which future researchers shall conduct further research.

\section{Literature Review \\ Theoretical Review \\ The Benefit Theory}

The benefit - based theory was popular in the late 18th and early 19th centuries, but its popularity reduced when John Stuart Mills introduced the ability to pay tax theory in 1872 . Erik, 1929 also supported this introduction of the ability to pay tax theory in 1919 (Aaron, Henry, \& Martin, 1976). The Benefits theory means the more a person gets benefits from the government, the more a person should pay tax and vice versa. A citizen should pay tax in proportion to benefits derived (Elmi et al 2015). Payment of tax in relation to the benefit derived seems unrealistic. Benefit Theory of taxation states that an agent that pays tax should enjoy the benefit of tax paid regarding goods and services (Elmi et al 2015).

According to this theory, the state should levy taxes according to benefit conferred by them. This means that the more benefit a person derives from the activities of the state, the more he should pay to the government. This theory seeks to ensure that each individuals tax obligation are as far as possible based on the benefits that he/she receives from the enjoyment of public services (Elmi et al 2015).

The benefit tax theory states that people should consider the benefits they receive from government expenditures before they pay tax (Jorge Martinez, 2001). This theory fits concepts of horizontal and vertical equity. It considers both revenue and expenditure. One of the drawbacks of the benefits tax theory is a measurement of how individuals benefit and use tax. Also, another drawback is if the poor benefit most from public expenditures, it may not make sense to ask them to pay for it (Martinez, 2001).

\section{Ability to Pay Theory}

According to Stephen , 2015, the principle of ability to pay theory of taxation started in the 16th century. It was further extended by the Swiss philosopher Jean Jacques Rousseau (1712-1778), and the French political economist Jean Baptiste say (1767-1832). This theory is considered the most equitable tax system (Stephen, 2015). Ability to pay theory of taxation is more widely accepted principle based on equity or justice (OBARA \&Nangih, 2017). Individual capacity should be given serious consideration before taxes are determined (Atawodi \& Ojeka S, 2012). The ability to pay principle of taxation asserts that the amount of tax levied on an economic entity should be directly proportioned to the ability of the entity to pay taxes, therefore a person having higher income and wealth should be taxed more and less tax should be levied on those having low income and wealth provided other things remain constant or the same. The phrase "ability to pay" does not 
necessarily ensure that individuals can afford their taxes as affordability can be subjective (Stephen , 2015).

\section{Optimal Tax Theory}

The foundation of the optimal tax theory is the wish of Government to raise a certain sum from taxation (Musau, 2015). There is need for the government to balance the ambition of raising tax optimally with the ability of her citizens to pay tax. According to (Emmanuele, 2012), a good tax system should consider efficiency, transparency, equity, stability, cheapness, and flexibility. Therefore, the government should not increase the tax burden of its citizens and at the same time maximize the welfare of the whole society (Emmanuele, 2012). Given the fall in oil prices globally, the government considers tax as a real source of increasing revenue. The ideal tax is expected to be centered on welfare economic principles. The goal of government is to maximize social welfare (Emmanuele, 2012). One of the criticisms of optimal tax theory which among other things prescribes that each good in an economy should be taxed at a separate rate, higher for necessities and lower for things with good substitutes is that it ignores the administrative costs of tax systems.

\section{Theory of Planned Behavior (TPB)}

The Theory of Planned Behavior was proposed by (Ajzen, 1985)as an extension of the Theory of Reasoned Action, which had been proposed a decade earlier, by (Fishbein \& Ajzen , 1975). According to the Theory of Reasoned Action, people are more likely to do a behavior if they evaluate the suggested behavior as having positive results (attitude) and if they think their significant others want them to perform the behavior (subjective norm). A high correlation of attitudes and subjective norms to behavior has been confirmed in many studies. However, the same authors have raised a counter argument against the high relationship between attitude, subjective norms and behavior. They argued that because of circumstantial limitations, attitude and subjective norms do not always lead to behavior. To improve on the predictive power of the Theory of Reasoned Action Ajzen added a new component "perceived behavioral control" to help account for behaviors that arise where an individual's control over the behavior is incomplete. By this, he extended the Theory of Reasoned Action to include the role of non-volition in predicting behavior. The extended version is called the theory of planned behavior.

According to Fishbein \& Ajzen (1975), the TPB is comprised of six constructs that collectively represent a person's actual control over the behavior;

Attitudes - This refers to the degree to which a person has a favorable or unfavorable evaluation of the behavior of interest. It entails a consideration of the outcomes of performing the behavior.

Behavioral intention - This refers to the motivational factors that influence a given behavior where the stronger the intention to perform the behavior, the more likely the behavior will be performed.

Subjective norms - This refers to the belief about whether most people approve or disapprove of the behavior. It relates to a person's beliefs about whether peers and people of importance to the person think he or she should engage in the behavior.

Social norms - This refers to the customary codes of behavior in a group or people or larger cultural context. Social norms are considered normative, or standard, in a group of people. 
Perceived power - This refers to the perceived presence of factors that may facilitate or impede performance of a behavior. Perceived power contributes to a person's perceived behavioral control over each of those factors.

Perceived behavioral control - This refers to a person's perception of the ease or difficulty of performing the behavior of interest. Perceived behavioral control varies across situations and actions, which results in a person having varying perceptions of behavioral control depending on the situation. This construct of the theory was added later, and created the shift from the Theory of Reasoned Action to the Theory of Planned Behavior.

There are several limitations of the TPB, which include the following:

It assumes the person has acquired the opportunities and resources to be successful in performing the desired behavior, regardless of the intention.

It does not account for other variables that factor into behavioral intention and motivation, such as fear, threat, mood, or past experience.

While it does consider normative influences, it still does not take into account environmental or economic factors that may influence a person's intention to perform a behavior.

It assumes that behavior is the result of a linear decision-making process, and does not consider that it can change over time.

While the added construct of perceived behavioral control was an important addition to the theory, it doesn't say anything about actual control over behavior.

The time frame between "intent" and "behavioral action" is not addressed by the theory. Therefore according to the TPB the decision to be tax compliant or not to be tax compliant depends on constructs such as attitude, behavioral intention, subjective norms, social norms, perceived power and perceived behavioural control of the tax payer.

\section{History of Taxation in Uganda}

According to Uganda Revenue Authority, Publication, 2015, taxation as understood today was introduced in East Africa by the early British colonial administrators through the system of compulsory public works such as road construction, building of administrative headquarters and schools, as well as forest clearance and other similar works.

The first formal tax, the hut tax, was introduced in 1900. This is when the first common tariff arrangements were established between Kenya and Uganda. Through this, Ugandans started paying customs duty as an indirect tax, which involved imposition of an ad valorem import duty at a rate of $5 \%$ on all goods entering East Africa, through the port of Mombasa and destined for Uganda. A similar arrangement was subsequently made with German East Africa (Tanganyika) for goods destined for Uganda that entered East Africa through Dar-es- Salaam and Tangaports. This gave rise to revenue which was remitted to Uganda.

The Protectorate government heavily relied on customs duties to fund its programs, yet the indigenous Africans were not engaging in activities that would propel the growth of the monetary economy. Accordingly, government introduced a flat rate poll tax that was imposed on all male adults. The requirement to pay tax forced the indigenous Ugandans to enter the market sector of the economy through either selling their agricultural produce or hiring out their services. The tax burden was later increased by the introduction of an additional tax to finance local governments. This culminated into the first tax legislation in 1919 under the Local Authorities' Ordinance. 
In 1953 , following recommendations by a committee headed by Mr. C.A.G Wallis, graduated personal tax was introduced to finance local governments.

Income tax was introduced in Uganda in 1940 by a Protectorate ordinance. It was mainly payable by the Europeans and Asians but was later on extended to Africans. In 1952, the ordinances were replaced by the East African Income Tax Management Act, which laid down the basic legal provisions found in the current income tax law. The East AfricanIncomeTaxManagementActof1952wasrepealed and replaced by the East African Income Tax Management Act of 1958.

The administration of both income tax and customs duty was done by departments of the East African Community (EAC) until its collapse. Under the EAC dispensation, there were regional taxing statutes and uniform administration but the national governments (or partner states, as they were called) retained the right to define tax rates.

After the breakup of the EAC, the tax departments were transferred to the Ministry of Finance with the transfer of the Income Tax Department in 1974; followed by the Customs Departmentin1977. In 1991, the function of administering Central government taxes was shifted from the Ministry of Finance to the Uganda Revenue Authority, a body corporate established by an Act of parliament.

\section{Tax laws in Uganda}

Administration of Uganda's Tax system is governed by the following laws, The constitution of the Republic of Uganda 1995, as amended in 2005; The Public Finance Management Act Cap 149 as amended in 2015; The Contingencies Fund Act Cap 150; The local Government Act, cap 243, The Income tax Act, cap 340 as amended, The Value Added Tax Act, cap 349 as amended ; The East African Excise management Act 1970, cap28, as amended, The Stamps Act, cap 342; The Traffic and Road Safety Act, 1998, cap 361; The Gaming and Pool Betting (Control and Taxation) Act, Cap 292; The East African Community Custom Management Act, 2004, Customs Tariff Act. Cap337; Excise Tariff Act Cap 338; and The Finance Acts. 


\section{Conceptual Framework \\ Independent Variables \\ Variable}

Dependent

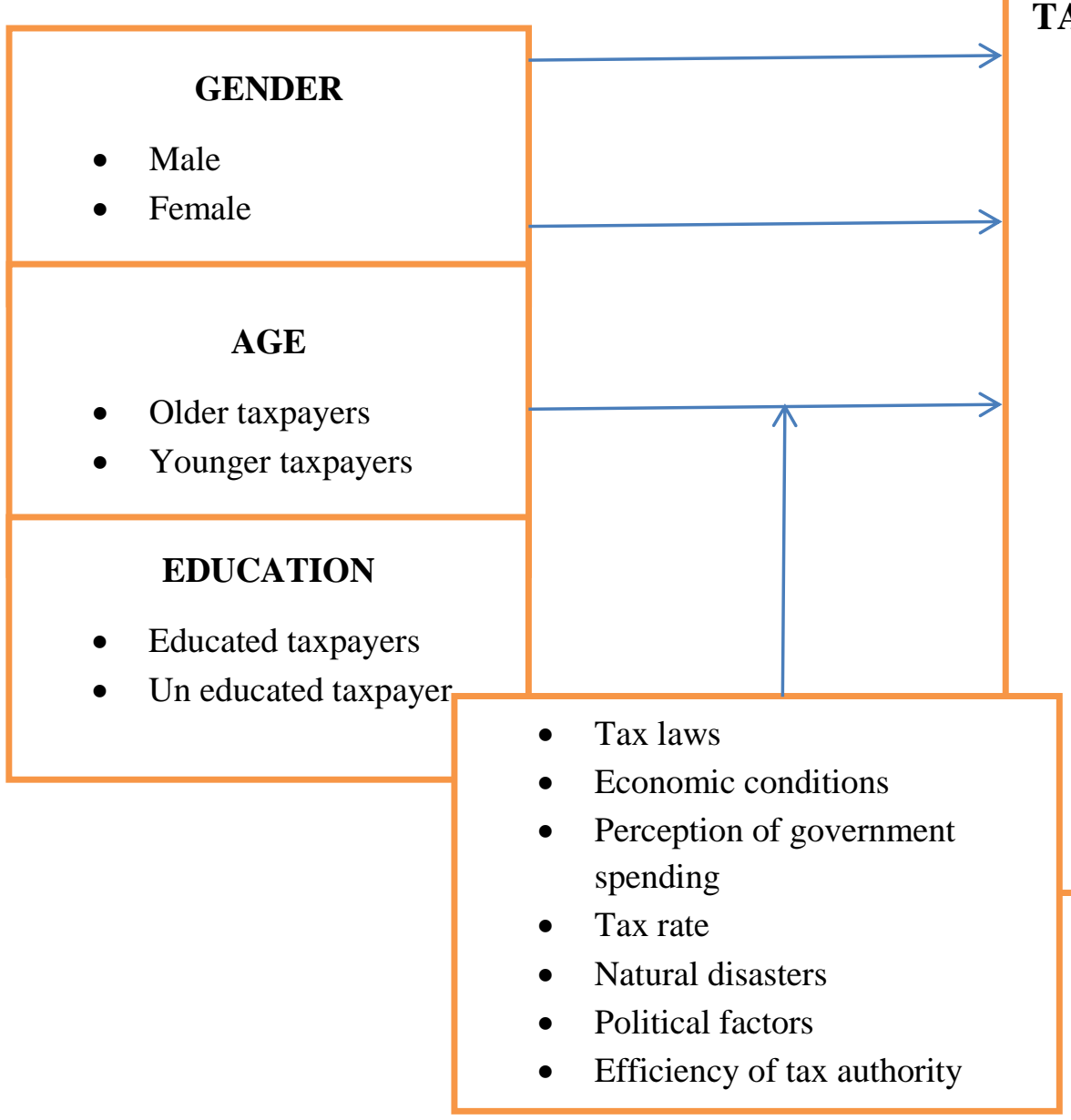

TAX COMPLIANCE

- Non tax evasion

- Non tax avoidance

- Reporting requirements

- Tax gap

\section{Methodology}

The study was conducted to examine the influence of demographic factors on tax payer compliance in Uganda. The study used administrative data obtained from Uganda Revenue Authority on a survey conducted by the authority on "a survey on attitudes to tax morale and compliance, and the role URA can play in improving tax morale and compliance in the country". Data was obtained from individual tax payers sampled from central Ugandan, Kampala city. Survey questionnaire was formulated using a likert scale ranging from Strongly Agree (1) to Strongly Disagree (5) to provide information on tax morale and compliance. The survey questionnaires were distributed to 284respondents, of which 284 responses were received, reflecting a response rate of $100 \%$. The survey questionnaire was designed in such a manner that it had two sections. Section A captured general information like; gender, age, marital status, education level, among others. Section B contained questions on tax morale and compliance. Data was analyzed using the Statistical Package for Social Scientists.

\section{Data Analysis}

Data was analyzed using the Statistical Package for Social Scientists from where Factor analysis and Correlational analysis was done to establish the influence of demographic factors on taxpayer compliance. 
Table 2: Demographic statistics

\begin{tabular}{|c|c|c|c|}
\hline Variable & Freq. & Percent & Cum. \\
\hline \multicolumn{4}{|l|}{ Gender } \\
\hline Female & 142 & 50 & 50 \\
\hline Male & 142 & 50 & 100 \\
\hline Total & 284 & 100 & \\
\hline \multicolumn{4}{|l|}{ Age } \\
\hline Below 40 & 118 & 41.6 & 41.6 \\
\hline 41 and above & 166 & 58.5 & 100.0 \\
\hline Total & 284 & 100 & \\
\hline \multicolumn{4}{|l|}{ Education category } \\
\hline No formal education & 1 & 0.35 & 0.35 \\
\hline secondary school(O'level) & 5 & 1.77 & 2.13 \\
\hline secondary school(A'level) & 8 & 2.84 & 4.96 \\
\hline Vocational Training & 20 & 7.09 & 12.06 \\
\hline University Education(Degree) & 133 & 47.16 & 59.22 \\
\hline $\begin{array}{l}\text { Postgraduate } \\
\text { education(Masters) }\end{array}$ & 106 & 37.59 & 96.81 \\
\hline Doctorate & 9 & 3.19 & 100 \\
\hline Total & 282 & 100 & \\
\hline
\end{tabular}

Source: Author generated from raw data of a survey done by Uganda Revenue Authority Table 2 above shows that the number of female and male taxpayers was the same at 142, while the elderly tax payers were more (166) than the younger taxpayers (118). All the taxpayers except 1 , had attained formal education that ranged from secondary to doctorate.

Table 3: Compliance

\begin{tabular}{|l|l|c|c|c|c|c|}
\hline $\begin{array}{l}\text { Demographic } \\
\text { factors }\end{array}$ & \multicolumn{1}{|c|}{ Variable } & Obs & Mean & Std.dev. & Min & Max \\
\hline \multirow{2}{*}{ Age group } & Below 40 & 118 & 2.69 & 0.48 & 1.83 & 4.22 \\
\cline { 2 - 8 } & 41 and Above & 165 & 2.61 & 0.40 & 1.00 & 3.61 \\
\hline \multirow{2}{*}{ Gender } & Female & 142 & 2.38 & 0.59 & 1.00 & 3.56 \\
\cline { 2 - 7 } & Male & 141 & 2.64 & 0.41 & 1.83 & 4.22 \\
\hline \multirow{2}{*}{$\begin{array}{l}\text { Education } \\
\text { category }\end{array}$} & No formal education & 1 & 2.56 &. & 2.56 & 2.56 \\
\cline { 2 - 8 } & $\begin{array}{l}\text { secondary school } \\
\text { (Ordinary level) }\end{array}$ & 5 & 2.49 & 0.27 & 2.11 & 2.88 \\
\cline { 2 - 8 } & $\begin{array}{l}\text { secondary } \\
\text { school(Advanced level) }\end{array}$ & 8 & 2.27 & 0.57 & 1.00 & 3.00 \\
\cline { 2 - 8 } & Vocational Training & 20 & 2.51 & 0.58 & 1.06 & 3.50 \\
\cline { 2 - 8 } & $\begin{array}{l}\text { University Education } \\
\text { (Degree) }\end{array}$ & 132 & 2.55 & 0.51 & 1.11 & 3.67 \\
\cline { 2 - 8 } & $\begin{array}{l}\text { Postgraduate education } \\
\text { (Masters) }\end{array}$ & 106 & 2.48 & 0.53 & 1.11 & 4.22 \\
\cline { 2 - 8 } & Doctorate & 9 & 2.55 & 0.66 & 1.06 & 3.17 \\
\hline
\end{tabular}


Source: Author generated from raw data of a survey done by Uganda Revenue Authority

\section{Factor Analysis}

In order to reduce on the number of variable for tax compliance, factor analysis a multivariate approach which caters for ordinal variables was used. Those variables that tended to load higher with values of 0.5 were kept for the next level of analysis (Table 4). Using the Factor Analysis approach, four factors were adequate enough to explain the variation in the data since they had Eigen value above one (Table 3). The four factors were able to explain up to $88 \%$ percent of the information related to tax compliance. Further variable selection were based on Kaiser (1974) test for sampling adequacy (Table 5). Using this approach, those variables that had scores of 0.8 and above were selected for the next level of analysis. This is because they contained much information that would explain tax compliance. Tax compliance variable was then generated by taking the row means of the selected variables from factor analysis.

Table 4: Eigen values

\begin{tabular}{|l|l|l|l|l|}
\hline Factor & Variance & Difference & Proportion & Cumulative \\
\hline Factor1 & 2.70 & 0.46 & 0.29 & 0.29 \\
\hline Factor2 & 2.24 & 0.18 & 0.24 & 0.54 \\
\hline Factor3 & 2.06 & 0.90 & 0.22 & 0.76 \\
\hline Factor4 & 1.16 & 0.39 & 0.13 & 0.88 \\
\hline Factor5 & 0.76 & 0.18 & 0.08 & 0.97 \\
\hline
\end{tabular}

Source: Author generated from raw data of a survey done by Uganda Revenue Authority LR test: independent vs. saturated: $\operatorname{chi} 2(276)=1771.99$ Prob $>$ chi $2=0.0000$

Table 5: Rotated factors loading

\begin{tabular}{|l|l|l|l|l|l|l|l|l|l|}
\hline Factor1 & Factor2 & Factor3 & Factor4 & Factor5 & Factor6 & Factor7 & Factor8 & Factor9 & \\
\hline Factor1 & 0.67 & 0.43 & 0.56 & -0.04 & -0.07 & 0.05 & -0.11 & 0.15 & 0.06 \\
\hline Factor2 & -0.43 & 0.78 & 0.01 & 0.25 & 0.33 & 0.04 & 0.15 & -0.06 & -0.06 \\
\hline Factor3 & 0.14 & -0.12 & -0.10 & 0.82 & -0.18 & 0.47 & 0.05 & 0.06 & 0.15 \\
\hline Factor4 & -0.31 & -0.39 & 0.78 & 0.12 & 0.28 & 0.09 & 0.12 & -0.10 & -0.12 \\
\hline Factor5 & 0.41 & -0.11 & -0.24 & -0.09 & 0.77 & 0.27 & 0.14 & -0.16 & -0.02 \\
\hline Factor6 & -0.15 & 0.03 & 0.05 & -0.39 & -0.10 & 0.52 & 0.21 & -0.13 & 0.61 \\
\hline Factor7 & 0.12 & -0.14 & -0.02 & 0.28 & 0.23 & -0.49 & 0.08 & -0.12 & 0.29 \\
\hline Factor8 & 0.03 & -0.02 & 0.01 & 0.01 & 0.04 & -0.29 & 0.61 & 0.44 & 0.27 \\
\hline Factor9 & 0.19 & 0.07 & 0.02 & 0.03 & -0.28 & -0.13 & 0.48 & -0.71 & -0.20 \\
\hline Factor10 & -0.04 & 0.04 & 0.05 & 0.08 & 0.13 & -0.18 & -0.52 & -0.38 & 0.38 \\
\hline Factor11 & -0.02 & 0.03 & 0.07 & 0.08 & -0.03 & -0.23 & 0.01 & -0.04 & 0.48 \\
\hline Factor12 & 0.01 & 0.02 & 0.00 & 0.00 & -0.12 & 0.03 & 0.08 & -0.25 & 0.06 \\
\hline Factor13 & -0.01 & -0.01 & -0.02 & 0.00 & -0.01 & -0.01 & -0.04 & -0.04 & 0.09 \\
\hline
\end{tabular}

Source: Author generated from raw data of a survey done by Uganda Revenue Authority 
Table 6: Kaiser-Meyer-Olkin measure of sampling adequacy

\begin{tabular}{|l|l|}
\hline Variable & Kmo \\
\hline q0010_0001 & 0.85 \\
\hline q0010_0002 & 0.76 \\
\hline q0010_0003 & 0.72 \\
\hline q0010_0004 & 0.81 \\
\hline q0010_0005 & 0.86 \\
\hline q0010_0006 & 0.51 \\
\hline q0010_0007 & 0.58 \\
\hline q0010_0008 & 0.83 \\
\hline q0010_0009 & 0.61 \\
\hline q0010_0010 & 0.78 \\
\hline q0010_0011 & 0.49 \\
\hline q0011_0001 & 0.69 \\
\hline q0011_0002 & 0.69 \\
\hline q0011_0003 & 0.53 \\
\hline q0011_0004 & 0.67 \\
\hline q0011_0005 & 0.63 \\
\hline q0012_0001 & 0.83 \\
\hline q0012_0002 & 0.84 \\
\hline q0012_0003 & 0.88 \\
\hline q0012_0004 & 0.77 \\
\hline q0012_0005 & 0.89 \\
\hline q0012_0006 & 0.86 \\
\hline q0012_0007 & 0.80 \\
\hline q0012_0008 & 0.85 \\
\hline Overall & 0.80 \\
\hline $5004 c e$. $04 t h o r$ & 8919 \\
\hline
\end{tabular}

Source: Author generated from raw data of a survey done by Uganda Revenue Authority Correlational Analysis

Gender

Table 7: t-test to assess for significance of gender

\begin{tabular}{|l|l|l|l|l|l|}
\hline Group & Obs & Mean & Std.Err. & \multicolumn{2}{|l|}{ [95\% Conf. Interval] } \\
\hline Female & 142 & 2.38 & 0.05 & 2.29 & 2.48 \\
\hline Male & 141 & 2.64 & 0.03 & 2.57 & 2.71 \\
\hline Combined & 283 & 2.51 & 0.03 & 2.45 & 2.57 \\
\hline Diff & & -0.26 & 0.06 & -0.38 & -0.14 \\
\hline
\end{tabular}

Source: Author generated from raw data of a survey done by Uganda Revenue Authority diff $=$ mean(Female) $\quad-$ mean(Male) $\quad t=-4.2869$

Ho: diff $=0 \quad$ degrees of freedom $=281$

Ha: diff $<0$

$\operatorname{Pr}(\mathrm{T}<\mathrm{t})=0.0000$
Ha: diff $\quad !=0$

$\operatorname{Pr}(\mathrm{T}>\mathrm{t})=\mathbf{0 . 0 0 0 0}$
Ha: diff $>0$

$\operatorname{Pr}(\mathrm{T}>$

t) =

1.0000 
The above shows the assessment of gender on tax compliance. On average females tended to be more tax compliant (2.38) as compared to male (2.64) implied less compliance. A ttest was used to test for significance about the mean responses on compliance about the two gender groups and a $p=0.0000<0.05$ implied that women were more tax complaint as compared to male. This is because women tend to be more anxious about the tax officer than men.

Age

Table 8: t-test to assess for significance of age

\begin{tabular}{|l|l|l|l|l|l|}
\hline Group & Obs & Mean & Std.dev. & [95\% Conf. Interval] \\
\hline Below 40 & 118 & 2.57 & 0.05 & 2.48 & 2.67 \\
\hline $\begin{array}{l}41 \text { and } \\
\text { above }\end{array}$ & 165 & 2.47 & 0.04 & 2.39 & \\
\hline Combined & 283 & 2.51 & 0.03 & 2.45 & 2.55 \\
\hline Diff & 0.10 & 0.06 & & -0.02 & 2.57 \\
\hline
\end{tabular}

Source: Author generated from raw data of a survey done by Uganda Revenue Authority diff $=$ mean $(1)-\quad \operatorname{mean}(2) \mathrm{t}=1.6140$

Ho: diff $=0$ degrees of freedom $=281$

Ha: diff $<0 \quad$ Ha: diff $\quad$ != $0 \quad$ Ha: diff $>0$

$\operatorname{Pr}(\mathrm{T}<\mathrm{t})=0.9462 \quad \operatorname{Pr}(\mathrm{T}>\mathrm{t}) \quad \mathbf{0 . 1 0 7 7} \quad \operatorname{Pr}(\mathrm{T}>\mathrm{t})=0.0538$

To assess whether age was related to tax compliance a t-test was used. Finding using the ttest however indicated that age did not influence tax compliance since the relationship was not significant. At all age categories, tax compliance score tended to be neutral which implied less tax compliance.

\section{Education}

Table 9: ANova

\begin{tabular}{|l|l|l|l|l|l|}
\hline Source & SS & Df & MS & F & Prob>F \\
\hline $\begin{array}{l}\text { Between } \\
\text { groups }\end{array}$ & 0.77 & 6.00 & 0.13 & 0.46 & 0.84 \\
\hline $\begin{array}{l}\text { Within } \\
\text { groups }\end{array}$ & 75.91 & 274.00 & 0.28 & & \\
\hline Total & 76.68 & 280.00 & 0.27 & & \\
\hline
\end{tabular}

Source: Author generated from raw data of a survey done by Uganda Revenue Authority In assessing the influence of education on tax compliance, ANOVA was used. This was because education level had seven brackets making ANOVA the most appropriate test statistic. Finding from the analysis indicated that whether someone is educated or not, they tended to be less tax complaint since this relationship was not significant.

\section{limitations to Study}

Data collection was done at a single point in time and hence did not take care of the changes that may occur overtime. 
The study population was limited only to sole proprietors with in Kampala city who are registered by Uganda Revenue Authority, therefore may not be used for generalization because Kampala has unique economic, social and political factors compared to other parts of the country.

The study is a one-off study in that such a study was not carried out before hence it does not make comparisons over periods of time possible.

\section{Conclusion}

From the findings it can be concluded that gender has a significant effect on taxpayer compliance, while age and education level do not have a significant effect on taxpayer compliance. Gender was significant in that female taxpayers were more compliant than their male counterparts. This is due to the fact that women tend to be more anxious about the tax officer than men. Male taxpayers are also greater risk takers than the female taxpayers and this explains why they comply less than the female taxpayers.

In Uganda of recent, there has been increased women empowerment and encouragement of women to participate in entrepreneurial economic activities. A lot of entrepreneurial education is being carried out from which women are advised to carry on business in line with acceptable business ethics one of which is compliance to tax obligations. Also in Uganda, women in business at business ventures as the main source of livelihood and therefore complying with tax obligations is seen as one of such factors for ensuring continuity of business.

In Uganda general, the context within which the tax payer does business influences their attitude and behavioral intention to tax compliance. This is supported by the Theory of Planned Behavior that states that, the decision to be tax compliant or not to be tax compliant depends on constructs such as attitude and behavioral intentions among others. Given that women empowerment and entrepreneurial education for women positively influences their tax compliance attitude, this paper argues for its significance in tax compliance.

\section{Recommendations}

Government should introduce policies that should make tax compliance friendlier. For example government should conduct country wide tax education for owners of small scale businesses and sole proprietors, through conducting workshops and seminars among other methods. Government should also introduce incentives for voluntary tax compliance

\section{References}

Aaron, Henry, \& Martin, M. (1976). Public Goods and Income Distribution_Reply to Geoffrey Brennan, "The distributional Implications of Public Goods". Econometrica, 30, 907920.

Ajzen, I. (1985). From intentions to actions: Atheory of planned behaviour: From Cognition to behaviour (pp 11039). Actionocontrol.

Allingham, M. G., \& Sandmo, A. (1972). 'Income Tax Evasion: A Theoretical Analysis'. Journal of Public Economics, 1(3), 323-338.

Alm, J., Cherry, T., Jones, M., \& Mckee, M. (2010). Taxpayer information assistance services and tax compliance behaviour. Journal of Economic Psychology, 31, 577-586.

Amina, \& Sniy. (2015). Tax compliance and its detaerminants, the case of Jimma zone. International Journal of Research in Social Sciences, 6(2), 7-21. 
Atawodi, O. W., \& Ojeka S , S. A. (2012). Factors that affect tax compliance among small and medium enterprises (SMEs) in North Central Nigeria. International Journal of Business and Management, 6(2), 87-96.

Ayoki, M., Obwona, M., \& Ogwapus, M. (2005). Tax Reforms and Domestic Revenue Mobilization in Uganda; Global Development Network (GDN). Washington, D.C.

Bhatia, H. L. (1976). Public Finance (19th edition ed.). New Delhi: Vikas Publishing House Pvt Ltd.

Cadsby, C. B., Maynes, E., \& Trivedi, V. U. (2006). Tax compliance and obedience to autharity at home and in the lab: A new experimental approach. Experimental Economics, 343359.

Chan, C. W., Troutman, C. T., \& O'Bryan, D. (2000). An expected model of taxpayer compliance: Empirical evidence fro the United States and Hong Kong, Auditing and Taxation. Journal of International Accounting, 83-103.

Chang, O. H., Nichols, D. R., \& Schultz, J. J. (1987). Taxpayers attitudes toward tax audit risk. Journal of Economic Psychology, 8(3), 299-309.

Clofter, C. T. (1983). Tax Evasuion and Tax Rates: An analysis of individual returns. . The Review of Economics abd Statistics, 65(3), 363-373.

Dubin, J. A., \& Wilde, L. L. (1988). An empirical analysis of federal income tax auditing and compliance. National tax Journal, 41(1), 61-74.

Dubin, J. A., Graetz, M. A., \& Wilde, L. L. (1987). Are we a nation of tax cheater? New econometric evidance on tax compliance. American Economic Review.

Dubin, J. A., Graetz, M. J., \& Wilde, L. L. (1990). The effect of audit rates on the federal individual income tax, 1977-1986. National Tax Journal, 43(4), 395-409.

Elmi, A., Kerosi, E., \& Ibrahim, T. O. (2015). Relationship between Tax Compliance Barriers and Governments Revenue Generation at Gobonimo Market in Somaliland.

Emmanuele, C. (2012). Economics of taxation: Normative and Positive theories. Hauppauge, NewYork: Npva Science Publishers, Inc.

Erik, L. (1929). Some Contraversial Questions in Theory of Taxation.

Fagbeni, T. O., \& Abogun. (2015). Factors influencing voluntary tax compliance of small and meduim scale enterprises in Kwara state Nigerioa.

Fischer, C. M., Wartick, M., \& Mark, M. M. (1992). Detection Probability and Taxpayer Compliance: A review of the Literature. Journal of Accounting Literature, 11(1).

Fishbein, M., \& Ajzen , I. (1975). Belief, Attitude, Intention and behaviour: An introduction to theory and research.

Fjeldstad, O. H., \& H C, a. S. (2012). "Peoples view of taxation in Africa, Research on determinants of tax compliance." International center for tax and development (ICTD). CHR-michelsen Institution.s.I..s.n.

Fjeldstad, O. H., \& Semboja, J. (2001). Why people pay taxes: the case of the development levy in Tanzania. World Development.

Friedland, N., Maital, S., \& Rutenberg, A. (1978). A simulation study of income tax evasion. Journal of Public Economics, 10(1), 107-116.

Hasseldine, J., \& Hite, P. (2003). Framing, Gender and tax compliance. Journal of Economic Psychology, 24, 517-533.

Jackson, B. R., \& Milliron, V. C. (1986). Tax Compliance Research: Findings, problems and prospects. Journal od Accounting Literature, 5, 125-165.

James , S., \& Alley, C. (2002). Tax Compliance, Self-Assesment and Tax Administration. 
James, S., \& Alley, C. (1999). 'Tax Compliance, Self-Assesment andd Tax Administration in New Zealand - is the Carrot or Stick More Appropriate to Encourage Compliance?'. New Zealand Journal of Taxation Law, 5(1), 3-11.

Jorge Martinez, V. (2001). Tax Morale and Tax Evasion in Latin America.

Kangave , J. (2005). Improving tax aAdministration; A case study of the Uganda Revenue Authority. Journal of African Law, 49(2), 145.

Kayaga , L. (2007). Tax policy challanges facing developing countries: A case study of Uganda. A thesis for the Master RI/DZV4XHHQIV8QLYHUVLWI.

Kirchler, \& Cambridge, E. (2007). The Economic psychology tax behaviour.

Kirchler, E. (1999). Reactance to taxation: Employers attitude towards taxes. Journal of Socio-Economics, 28(2), 131-138.

Loo, E. C. (2006). The influence of the introduction of self-assesement on compliance behaviour of individual taxpayers in Malysia. PhD thesis. University of Sydney.

Lymer, A., \& Oats, L. (2009). Taxation: Policy and Practice (16th edition ed.). Birmingham: Fiscal Publication.

Mohani, A. (2001). Personal income tax non-compliance in Malysia. PhD thesis. Victoria University. Melbourne Australia.

Network, T. J. (2011). Annual report.

Network, T. J. (2011). Annual Report.

Niway, A. W. (2016). Determinanta of voluntary compliance behaviour evedence from SNNPR Ethiopia. International Journal of Science and Research, 5(12), 967-973.

Omagor , C., \& Mubiru, M. (2008). Entrrepreneurship: An intergrated approach (1st edition ed.). Kampala: Kabali and business books.

Palil, M. R. (2010). Tax knowledge and tax compliance determinants in self-assessment system in Malysia. A thesis submitted to the University of Birmingham for the degree of Doctor of Philosopphy.

Preager, \& Torgler, B. (2007). Tax Compliance and Tax Norale. Atheoretical and Empirical Analysis.

Richardson, G. (2006). The impact of tax fairness dimentions on tax compliance behaviour in an Asian jurisdiction: the case of Hong Kong. International tax Lournal, 29-42.

Romer, C., \& Romer, D. (2010). The Macroeconomic effects of tax changes: estimates based on a new measure of fiscal shocks. American Economic review.

Roth, J. A., Scholz, J. T., \& Witte, A. D. (1989). Taxpater compliance, an agenda for research; (Vol. 1). Philadeelphia: University of Pennysylvania.

Saad, N. (2010). Fairness, perceptions and compliance behaviour: The case of salaried taxpayers in Malysia after inplementation of of the self assesment system. eJournal of Tax Research, 8(1), 32-63.

Saad, N. (2010). Services and tax compliance behaviour. Journal of Economic Psychology, 31, 577-586.

Stephen , O. (2015). A casualty analysis between tax cpmpliance behaviour and Nigerian Economic Growth.

Tax Justice Network. (2011). Annual Report.

Tesfaye, A. (2015). Determinants of tax revenue in Ethiopia. MSC Thesis for partial fulfilment of the requirement of Master of Science in Accouting and Finance.AAU.

Tittle, C. (1980). Sanctions and Social Deviance: The questions of Deterrence. Connecticutt:praeger. 
Uganda Revenue Authority. (2014-2015). Annual Report.

Uganda Revenue Authority. (2015). Publication.

Uganda Revenue Authority. (2015-2016). Annual Report.

Uganda Revenue Authority. (2016-2017). Annual Report.

Uganda Revenue Authority. (2017/2018). Annual Report. Kampala.

Vazguez, J. M. (2001). Tax Morale and Tax Evasion in Latin Amarica.

Wahlund, R. (1992). Tax changes and economic behaviour: The case of tax evasion. Journal of Economic Psychology, 13, 657-677.

Warneryd, K. E., \& Walerud, B. (1982). Taxes and Economic behaviour:Some interview data on tax evasion in Sweden. Journal of Economic Psychology, 2,187-2,211. 